\title{
Drug-resistant tuberculosis in Northern Germany: a retrospective hospital-based study of 1,055 patients from 1984 until 1993
}

\author{
J. Borchardt, D. Kirsten, R. Jörres, C. Kroeger, H. Magnussen
}

\begin{abstract}
Drug-resistant tuberculosis in Northern Germany: a retrospective hospital-based study of 1,055 patients from 1984 until 1993. J. Borchardt, D. Kirsten, R. Jörres, C. Kroeger, H. Magnussen. (CERS Journals Ltd 1995.

ABSTRACT: For the past decade, there have been no data on the time course of drug-resistant tuberculosis and on risk factors for drug resistance in former West Germany.

We reviewed the medical records of all patients with positive cultures for Mycobacterium tuberculosis from 1984 until 1993 in a hospital near Hamburg. Drug-susceptibility testing was performed for isoniazid, rifampicin, ethambutol, and streptomycin, using the modified proportion method.

Of 1,055 patients, $9.6 \%$ had isolates resistant to one or more drugs. Of the isolates, $5.8 \%$ showed resistance to isoniazid or rifampicin and $1.8 \%$ to both isoniazid and rifampicin. There was no significant change of the resistance rate during the study period. Twenty six percent of 89 patients from South America, Africa or Asia had isolates resistant to one or more drugs, compared with $7.6 \%$ of 799 patients born in Germany (odds ratio (OR) 4.2; 95\% confidence interval (95\% CI) 2.5-7.3). Among patients born in Germany, 32\% of 101 patients with a history of prior antituberculosis drug therapy had resistant organisms, versus $4.2 \%$ of 698 patients without prior therapy (OR 10.7; 95\% CI 6.1-18.7). Resistance rates for 35 patients, who had been treated within the last 5 yrs, and for 65 patients, who had been treated more than 5 yrs ago, were 57 and 17\%, respectively (OR 6.6; 95\% CI 2.9-16.6).

Our results suggest that there is no increase in the proportion of drug-resistant tuberculosis in our hospital, and that patients with a recent history of antituberculosis drug therapy and patients from South America, Africa, or Asia are at high risk for drug resistance.
\end{abstract}

Eur Respir J., 1995, 8, 1076-1083.

Krankenhaus Großhansdorf, Zentrum für Pneumologie und Thoraxchirurgie, Großhansdorf, Federal Republic of Germany.

Correspondence: D. Kirsten Krankenhaus Großhansdorf Zentrum für Pneumologie und Thoraxchirurgie, Wöhrendamm 80 D-22927 Großhansdorf

Federal Republic of Germany

Keywords: Antitubercular agents Germany

microbial drug resistance multidrug-resistant tuberculosis Mycobacterium tuberculosis risk factors

Received: October 131994 Accepted after revision March 251995
Antituberculosis drug resistance has caused increasing concern in recent years within the industrialized world. This is due mainly to reports about a rise of drugresistant tuberculosis in the United States [1], most prominent in New York City. Drug resistance is known to impede tuberculosis control in developing countries [2]. Particularly disquieting is the emergence of multidrugresistant tuberculosis (defined as resistance to isoniazid and rifampicin, with or without resistance to other drugs) [3]. Several outbreaks of multidrug-resistant tuberculosis have been reported, most but not all involving patients with the acquired immunodeficiency syndrome (AIDS) $[4,5]$. The rise of drug-resistant tuberculosis in the United States has been accompanied by an increasing incidence of tuberculosis, attributed to the human immunodeficiency virus (HIV) epidemic, poverty, and a decline of tuberculosis control programmes [6].

Tuberculosis caused by mycobacteria resistant only to isoniazid can be successfully treated with a four drug regimen [7]. If resistance to isoniazid and rifampicin is present, the case fatality rate with standard antimicrobial therapy is similar to that without such therapy [8]. This has led to a resurgence of surgery in the treatment of tuberculosis [9], and to the application of immunotherapy as a novel therapeutic approach [10].

The incidence of notified cases of tuberculosis in Germany declined continuously to 17.3 per 100,000 in 1991 [11], and stabilized thereafter being 17.5 per 100,000 in 1993 [12]. One communication based on questionnaires returned from mycobacteriology laboratories throughout Germany indicates low overall resistance rates in 1991 and 1992 [13]. In the absence of any community-based study of drug-resistant tuberculosis in former West Germany in the past, these data provide little information as to the time course of drug-resistant tuberculosis. The last hospital-based study of antituberculosis drug resistance in former West Germany dates back to 1982 [14]. Low resistance rates have been reported for 1988 in former East Germany [15].

In order to determine the time course of drug-resistant tuberculosis within the last decade and to identify factors associated with drug resistance, we performed a 
retrospective analysis of all tuberculosis patients in our hospital from 1984 until 1993.

\section{Methods}

\section{Study population}

The Krankenhaus Großhansdorf near Hamburg is a referral centre for pulmonology and thoracic surgery with one ward for the treatment of patients with tuberculosis. It serves mainly the city of Hamburg and the surrounding predominantly rural state of Schleswig-Holstein. Using the laboratory records, all in-patients with positive cultures for Mycobacterium tuberculosis from January 1, 1984 until December 31, 1993 were identified and included in this study.

\section{Susceptibility testing}

Mycobacterial culture was performed with industrially manufactured Löwenstein-Jensen media (Haipha, Heidelberg, Germany), and further species identification was only performed if atypical growth was noted. During the whole study period, susceptibility testing was routinely performed with every first isolate for isoniazid, rifampicin, ethambutol, and streptomycin, using the modified proportion method [16]. Drug resistance was defined as growth on drug-containing medium greater than that on a control medium having been inoculated with $1 \%$ of the inoculum on the drug-containing medium. The concentrations of drugs used were $0.25 \mathrm{mg} \cdot \mathrm{L}^{-1}$ for isoniazid, $32.0 \mathrm{mg} \cdot \mathrm{L}^{-1}$ for rifampicin, $1.0 \mathrm{mg} \cdot \mathrm{L}^{-1}$ for ethambutol, and $4.0 \mathrm{mg} \cdot \mathrm{L}^{-1}$ for streptomycin.

\section{Demographic and clinical data}

The following data were drawn from the medical records: age, sex, country of birth (with the country boundaries defined as they were defined at the time of birth), years since arrival in Germany, residence (city of Hamburg versus other residence, with tourists and seamen being excluded from this classification), homelessness (no identifiable residence or sojourn in a shelter for the homeless, with tourists and seamen being considered not homeless), institutionalization (residence in a nursing home, a home for foreigners asking for asylum or for German citizens immigrating from other countries, a prison or a psychiatric hospital), employment in a medical institution, disease localization (with pleural disease considered as extrapulmonary and hilar lymphadenopathy included in pulmonary), presence of acid-fast bacilli in a sputum smear, bilateral versus unilateral disease, presence of cavitary lesions, prior active tuberculosis (before/after the introduction of streptomycin in 1947), prior antituberculosis drug therapy, years since last antituberculosis drug therapy, number of prior antituberculosis drug therapy courses, alcoholism (defined as having or having had problems with alcohol in the patient's or the physician's view), diabetes mellitus, immunosuppressive therapy (chemotherapy or long-term steroid therapy), HIV serostatus, intravenous drug use, male homosexuality.

\section{Statistical analysis}

The Chi-squared test was used for statistical analysis, and a p-value of less than 0.05 was considered to indicate statistical significance. A preliminary analysis revealed that variables having more than two categories could be summarized in order to obtain dichotomous variables for the subsequent statistical analysis presented in this paper. A multivariate analysis was performed by logistic regression for factors significantly associated with drug resistance in the univariate analysis. We computed odds ratios (OR) and 95\% confidence intervals (CI). In all analyses, the categories "unknown" and "undecided" (see tables 1 and 2) were treated as "missing", except for prior therapy where "unknown" was treated as "no" (see below).

Table 1. - Demographic characteristics of patients and proportion of patients with isolates resistant to one or more drugs

\begin{tabular}{|c|c|c|c|c|c|}
\hline & \multirow[t]{2}{*}{$\begin{array}{c}\text { Pts } \\
\mathrm{n}\end{array}$} & \multicolumn{2}{|c|}{$\begin{array}{l}\text { Resistant to } \\
\geq 1 \text { drugs }\end{array}$} & \multirow[t]{2}{*}{$\begin{array}{l}\text { Odds } \\
\text { ratio }\end{array}$} & \multirow[t]{2}{*}{ p-value* } \\
\hline & & & $\%$ & & \\
\hline Total & 1055 & 101 & 10 & & \\
\hline \multicolumn{6}{|l|}{ Age } \\
\hline$\leq 30 \mathrm{yrs}$ & 245 & 35 & 14 & 1.9 & $0.004 \dagger$ \\
\hline $31-45$ yrs & 278 & 25 & 9 & & \\
\hline $46-60$ yrs & 264 & 21 & 8 & & \\
\hline$>60$ yrs & 268 & 20 & 8 & & \\
\hline \multicolumn{6}{|l|}{ Sex } \\
\hline Female & 315 & 34 & 11 & 1.2 & NS \\
\hline Male & 740 & 67 & 9 & & \\
\hline \multicolumn{6}{|l|}{ Country of origin } \\
\hline Germany & 799 & 61 & 8 & 4.0 & $<0.0001^{+}$ \\
\hline Group I & 156 & 16 & 10 & & \\
\hline Group II & 89 & 23 & 26 & & \\
\hline Unknown & 11 & 1 & & & \\
\hline \multicolumn{6}{|c|}{ Resident in Germany } \\
\hline$\leq 3 \mathrm{yrs}$ & 95 & 24 & 25 & 1.9 & NS \\
\hline$>3 \mathrm{yrs}$ & 80 & 12 & 15 & & \\
\hline Unknown & 70 & 3 & & & \\
\hline \multicolumn{6}{|l|}{ Residence } \\
\hline Hamburg & 650 & 58 & 9 & 0.9 & NS \\
\hline Outside Hamburg & 380 & 37 & 10 & & \\
\hline None or abroad & 25 & 6 & & & \\
\hline \multicolumn{6}{|l|}{ Homelessness } \\
\hline Yes & 24 & 1 & & & \\
\hline No & 1031 & 100 & 10 & & \\
\hline
\end{tabular}

*: a univariate analysis was performed; Ns: not significant; Pts: patients. $\dagger: \leq 30$ yrs versus $>30$ yrs. ${ }^{+}$: Group II versus Germany and Group I. For countries included in Group I and Group II see table 3. 
Table 2. - Clinical characteristics of patients and proportion of patients with isolates resistant to one or more drugs

\begin{tabular}{|c|c|c|c|c|c|}
\hline \multirow[b]{2}{*}{ Total } & \multirow{2}{*}{$\begin{array}{c}\text { Pts } \\
\mathrm{n}\end{array}$} & \multicolumn{2}{|c|}{$\begin{array}{c}\text { Resistant to } \\
\geq 1 \text { drugs } \\
\mathrm{n}\end{array}$} & \multirow[t]{2}{*}{$\begin{array}{l}\text { Odds } \\
\text { ratio } \\
\%\end{array}$} & \multirow[t]{2}{*}{ p-value* } \\
\hline & & 101 & 10 & & \\
\hline $\begin{array}{l}\text { Localization } \\
\text { Pulmonary only } \\
\text { Both } \\
\text { Extrapulmonary only } \\
\text { Undecided }\end{array}$ & $\begin{array}{r}849 \\
129 \\
71 \\
6\end{array}$ & $\begin{array}{r}78 \\
10 \\
12 \\
1\end{array}$ & $\begin{array}{r}9 \\
8 \\
17\end{array}$ & 2.1 & $0.03 \dagger$ \\
\hline $\begin{array}{l}\text { Sputum smear } \\
\text { Acid-fast bacilli } \\
\text { No acid-fast bacilli } \\
\text { Unknown }\end{array}$ & $\begin{array}{r}714 \\
243 \\
21\end{array}$ & $\begin{array}{r}66 \\
21 \\
1\end{array}$ & $\begin{array}{l}9 \\
9\end{array}$ & 1.1 & NS \\
\hline $\begin{array}{l}\text { Pulmonary infiltrates } \\
\text { Bilaterally described } \\
\text { Unilaterally described } \\
\text { Undecided }\end{array}$ & $\begin{array}{r}543 \\
418 \\
17\end{array}$ & $\begin{array}{r}55 \\
31 \\
2\end{array}$ & $\begin{array}{r}10 \\
7\end{array}$ & 1.4 & NS \\
\hline $\begin{array}{l}\text { Cavitation } \\
\text { Described } \\
\text { Not described } \\
\text { Undescribed }\end{array}$ & $\begin{array}{r}525 \\
449 \\
4\end{array}$ & $\begin{array}{r}56 \\
32 \\
0\end{array}$ & $\begin{array}{r}11 \\
7\end{array}$ & 1.6 & NS \\
\hline $\begin{array}{l}\text { Prior therapy } \\
\text { Yes } \\
<0.0001^{+} \\
\text {No } \\
\text { Unknown }\end{array}$ & $\begin{array}{r}53 \\
870\end{array}$ & $\begin{array}{l}11 \\
50\end{array}$ & $\begin{array}{r}21 \\
6\end{array}$ & 6.1 & \\
\hline $\begin{array}{l}\text { Time since last therapy } \\
\leq 5 \mathrm{yrs} \\
>5 \mathrm{yrs} \\
\text { Unknown }\end{array}$ & $\begin{array}{r}49 \\
82 \\
1\end{array}$ & $\begin{array}{r}25 \\
14 \\
1\end{array}$ & $\begin{array}{l}51 \\
17\end{array}$ & 5.1 & $<0.0001$ \\
\hline $\begin{array}{l}\text { Prior therapies } \\
\geq 2 \\
1 \\
\text { Unknown }\end{array}$ & $\begin{array}{r}39 \\
90 \\
3\end{array}$ & $\begin{array}{r}18 \\
22 \\
0\end{array}$ & $\begin{array}{l}46 \\
24\end{array}$ & 2.6 & 0.01 \\
\hline $\begin{array}{l}\text { Alcoholism } \\
\text { Yes } \\
\text { No } \\
\text { Unknown }\end{array}$ & $\begin{array}{l}289 \\
600 \\
166\end{array}$ & $\begin{array}{l}23 \\
62 \\
16\end{array}$ & $\begin{array}{r}8 \\
10 \\
10\end{array}$ & 0.8 & NS \\
\hline $\begin{array}{l}\text { Diabetes mellitus } \\
\text { Yes } \\
\text { No }\end{array}$ & $\begin{array}{r}86 \\
969\end{array}$ & $\begin{array}{r}5 \\
96\end{array}$ & $\begin{array}{r}6 \\
10\end{array}$ & 0.6 & NS \\
\hline $\begin{array}{l}\text { Immunosuppressive the } \\
\text { Yes } \\
\text { No }\end{array}$ & $\begin{array}{r}\text { erapy } \\
20 \\
1035\end{array}$ & $\begin{array}{r}1 \\
100\end{array}$ & 10 & & \\
\hline $\begin{array}{l}\text { HIV serostatus } \\
\text { Positive } \\
\text { Negative } \\
\text { Unknown }\end{array}$ & $\begin{array}{r}4 \\
116 \\
835\end{array}$ & $\begin{array}{r}0 \\
21 \\
80\end{array}$ & $\begin{array}{r}18 \\
9\end{array}$ & & \\
\hline
\end{tabular}

*: a univariate analysis was performed; NS: not significant; Pts: patients; HIV: human immunodeficiency virus. $\dagger$ : extrapulmonary only versus pulmonary only and both (pulmonary and extrapulmonary); +: patients with no statement about prior therapy in their medical records were considered as not having been treated previously (see text).

\section{Results}

The laboratory records revealed 1,062 in-patients with positive cultures for Mycobacterium tuberculosis during the study period. In seven patients (five in 1985, one in 1987 , one in 1989), it was not possible to locate the corresponding medical records at the time of the study. The results of drug-susceptibility testing in these cases (all showing pansensitivity) were excluded from further analysis. For the remaining 1,055 patients, drug-susceptibility data were complete except for two patients (one in 1990 , one in 1992) in whom the results of ethambutolsusceptibility testing (showing resistance) had to be neglected, since the manufacturer had notified the laboratory that the respective charges of media contained too little ethambutol.

\section{Characteristics of patients}

Demographic and clinical characteristics of patients are presented in tables 1 and 2. Countries of origin of 245 foreign-born patients are shown in table 3 . One hundred and fifty six patients came from Europe, including the former Soviet Union and Turkey, with 61 patients from Turkey forming the single largest group of foreignborn patients. Eighty nine patients were born in South America, Africa, or Asia. The proportion of homeless patients was small. Of 49 patients who were known to live in an institution, three patients living in homes for foreigners had resistant isolates. Twenty nine patients were employed in medical institutions, and two of these had isolates resistant to streptomycin. In most patients, there was no explicit statement in the medical records with respect to prior antituberculosis drug therapy. However, among 151 patients with a history of tuberculosis after 1947, only 11 patients had records without a statement about prior therapy. In these 11 patients, the time of prior disease ranged from 1949 to 1968, and all isolates showed pansensitivity.

For statistical analysis, patients without a statement about prior therapy in their records were considered as not having been treated previously. Four patients were documented to be HIV-seropositive. Only a small proportion of medical records contained information on the presence of HIV risk factors. Five patients were known to use drugs intravenously and two male patients were known to be homosexual. None of these seven patients had resistant organisms.

\section{Drug resistance}

Of 1,055 patients, $101(9.6 \%)$ had isolates resistant to one or more drugs, with 55 isolates $(5.2 \%)$ showing resistance against isoniazid, $25(2.4 \%)$ against rifampicin, $16(1.5 \%)$ against ethambutol, and $59(5.6 \%)$ against streptomycin. Resistance to isoniazid or rifampicin was found in $61(5.8 \%)$. Of 38 patients $(3.6 \%)$ with organisms resistant to two or more drugs, $19(1.8 \%)$ had organisms resistant to both isoniazid and rifampicin. Resistance 
against three or more drugs was present in 11 cases $(1.0 \%)$, and resistance against all four drugs in $5(0.5 \%)$. Of 27 patients with isolates resistant to two drugs, 12 had isolates resistant to isoniazid and rifampicin, whereas 11 had isolates resistant to isoniazid and streptomycin.

Table 3. - Countries of origin of foreign-born patients and proportion of patients with isolates resistant to one or more drugs

\begin{tabular}{|c|c|c|}
\hline & $\begin{array}{c}\text { Pts } \\
\mathrm{n}\end{array}$ & $\begin{array}{c}\text { Resistant to } \\
\geq 1 \text { drugs } \\
n\end{array}$ \\
\hline \multicolumn{3}{|l|}{ Group 1} \\
\hline Austria & 4 & 0 \\
\hline Switzerland & 2 & 0 \\
\hline France & 1 & 0 \\
\hline Netherlands & 1 & 0 \\
\hline Sweden & 1 & 0 \\
\hline Finland & 1 & 0 \\
\hline Yugoslavia & 34 & 4 \\
\hline Greece & 5 & 0 \\
\hline Spain & 2 & 0 \\
\hline Portugal & 5 & 0 \\
\hline Soviet Union & 9 & 0 \\
\hline Poland & 18 & 1 \\
\hline Hungary & 2 & 0 \\
\hline Romania & 7 & 3 \\
\hline Bulgaria & 1 & 0 \\
\hline Turkey & 61 & 8 \\
\hline USA & 1 & 0 \\
\hline Canada & 1 & 0 \\
\hline \multicolumn{3}{|l|}{ Group II } \\
\hline Peru & 7 & 5 \\
\hline Argentina & 2 & 0 \\
\hline Morocco & 2 & 1 \\
\hline Algeria & 1 & 0 \\
\hline Egypt & 2 & 0 \\
\hline Jordan & 1 & 0 \\
\hline Syria & 1 & 0 \\
\hline Senegal & 2 & 2 \\
\hline Gambia & 5 & 0 \\
\hline Ivory Coast & 1 & 1 \\
\hline Nigeria & 1 & 0 \\
\hline Chad & 1 & 0 \\
\hline Ethiopia & 4 & 0 \\
\hline Kenya & 1 & 0 \\
\hline Mozambique & 1 & 0 \\
\hline Yemen & 2 & 2 \\
\hline Iran & 4 & 0 \\
\hline Afghanistan & 8 & 2 \\
\hline Pakistan & 10 & 3 \\
\hline India & 7 & 2 \\
\hline Sri Lanka & 1 & 0 \\
\hline Burma & 1 & 0 \\
\hline Thailand & 2 & 1 \\
\hline Vietnam & 7 & 1 \\
\hline Philippines & 5 & 0 \\
\hline Indonesia & 2 & 0 \\
\hline Oceania & 2 & 1 \\
\hline China & 4 & 1 \\
\hline Korea & 1 & 1 \\
\hline Japan & 1 & 0 \\
\hline
\end{tabular}

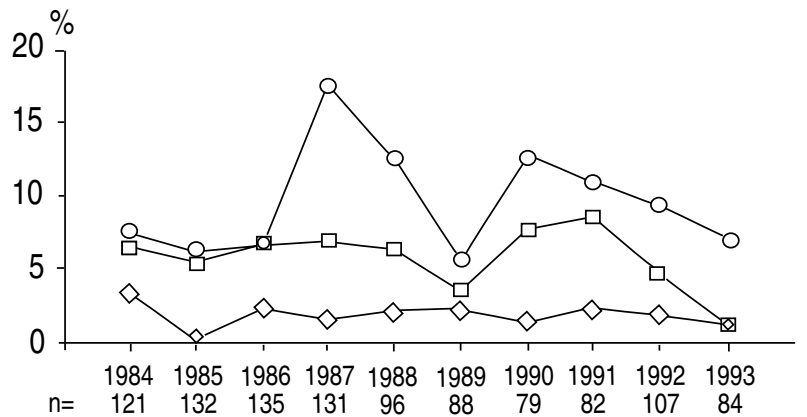

Fig. 1. - Annual proportion of isolates resistant to: one or more drugs ( - - - ) ; isoniazid (INH) or rifampicin (RIF), ( $\square-$ ); and both isoniazid and rifampicin $(\checkmark \checkmark)$.

\section{Time course of drug resistance}

The course of the annual proportion of patients with organisms resistant to one or more drugs, to isoniazid or rifampicin, and to both isoniazid and rifampicin is shown in figure 1 . There was no statistically significant increase in the rate of drug-resistant tuberculosis over the study period. The peak of resistance to one or more drugs in 1987 was due mostly to a peak in resistance against streptomycin $(13 \%)$. There was the same association with risk factors for drug resistance among these patients as among all patients with resistant isolates. Rates of both initial and acquired resistance (defined as resistance in the absence and in the presence of a history of prior antituberculosis drug therapy, respectively) remained stable, as well as the proportion of patients with a history of prior therapy. The percentage of patients from South America, Africa, or Asia increased from 5.9\% in 19841987 to $8.8 \%$ in $1988-1990$ and $13.2 \%$ in $1991-1993$. If these patients were excluded from analysis, the remaining population showed a similar pattern of resistance rates over time as the whole group; in particular, there was no substantial decrease of drug-resistant tuberculosis.

\section{Factors associated with drug resistance}

Table 4 shows the results of a multivariate analysis performed for factors significantly associated with resistance to one or more antituberculosis drugs in univariate analyses (tables 1 and 2). The high rate of drug resistance

Table 4. - Multivariate analysis of factors significantly associated with resistance to antituberculosis drugs in univariate analysis

\begin{tabular}{lccc}
\hline & $\begin{array}{c}\text { Adjusted } \\
\text { odds ratio }\end{array}$ & $95 \%$ CI & p-value \\
\hline Age $\leq 30$ yrs & 2.3 & $1.4-3.8$ & 0.002 \\
$\begin{array}{l}\text { Country of birth } \\
\text { in group II }\end{array}$ & 3.8 & $2.1-6.9$ & $<0.0001$ \\
$\begin{array}{l}\text { Extrapulmonary } \\
\text { localization only }\end{array}$ & 1.8 & $0.9-3.6$ & 0.11 \\
Prior therapy & 8.3 & $5.0-13.7$ & $<0.0001$ \\
\hline
\end{tabular}

95\% CI: 95\% confidence interval. For countries included in Group II see table 3. 
Table 5. - Characteristics of patients associated with resistance to antituberculosis drugs*

\begin{tabular}{|c|c|c|c|c|c|c|c|c|c|c|}
\hline & \multirow[t]{2}{*}{$\begin{array}{c}\text { Pts } \\
\mathrm{n}\end{array}$} & \multicolumn{3}{|c|}{$\begin{array}{l}\text { Resistant to } \\
\geq 1 \text { drugs }\end{array}$} & \multicolumn{3}{|c|}{$\begin{array}{l}\text { Resistant to } \\
\text { INH or RIF }\end{array}$} & \multicolumn{3}{|c|}{$\begin{array}{l}\text { Resistant to } \\
\text { INH and RIF }\end{array}$} \\
\hline & & $\%$ & OR & $95 \% \mathrm{CI}$ & $\%$ & OR & $95 \% \mathrm{CI}$ & $\%$ & OR & $95 \% \mathrm{CI}$ \\
\hline Birth in Group II country & 89 & 26 & \multirow[t]{2}{*}{4.2} & \multirow[t]{2}{*}{$2.5-7.3$} & 16 & \multirow[t]{2}{*}{2.0} & \multirow[t]{2}{*}{$1.4-2.8$} & 7 & \multirow[t]{2}{*}{2.3} & \multirow[t]{2}{*}{$1.4-3.8$} \\
\hline Birth in Germany & 799 & 7.6 & & & 4.5 & & & 1.4 & & \\
\hline \multicolumn{11}{|l|}{ Birth in Germany } \\
\hline Prior therapy & 101 & 32 & \multirow[t]{2}{*}{10.7} & \multirow[t]{2}{*}{$6.1-18.7$} & 26 & \multirow[t]{2}{*}{23.9} & \multirow[t]{2}{*}{$11.1-51.4$} & 9.9 & \multirow[t]{2}{*}{$\mathrm{NC}$} & \\
\hline No prior therapy** & 698 & 4.2 & & & 1.4 & & & 0.1 & & \\
\hline \multicolumn{11}{|c|}{ Prior therapy } \\
\hline$\leq 5 \mathrm{yrs}$ since last therapy & 35 & 57 & \multirow[t]{2}{*}{6.6} & \multirow[t]{2}{*}{$2.9-16.6$} & 51 & \multirow[t]{2}{*}{8.8} & \multirow[t]{2}{*}{$3.1-24.5$} & 26 & \multirow[t]{2}{*}{$\mathrm{NC}$} & \\
\hline$>5$ yrs since last therapy & 65 & 17 & & & 11 & & & 2 & & \\
\hline \multicolumn{11}{|c|}{$\leq 5$ yrs since last therapy } \\
\hline$\geq 2$ prior therapies & 19 & 74 & \multirow[t]{2}{*}{4.7} & \multirow[t]{2}{*}{$1.1-19.7$} & 68 & \multirow[t]{2}{*}{4.8} & \multirow[t]{2}{*}{$1.1-20.0$} & 42 & \multirow[t]{2}{*}{$\mathrm{NC}$} & \\
\hline 1 prior therapy & 16 & 38 & & & 31 & & & 6 & & \\
\hline \multicolumn{11}{|l|}{ No prior therapy } \\
\hline age $\leq 30$ yrs & 121 & 8.3 & \multirow[t]{2}{*}{2.6} & \multirow[t]{2}{*}{$1.2-5.8$} & 1.7 & \multirow{2}{*}{\multicolumn{2}{|c|}{ ns }} & 0.8 & \multirow{2}{*}{\multicolumn{2}{|c|}{$\mathrm{NC}$}} \\
\hline age $>30$ yrs & 577 & 3.3 & & & 1.4 & & & 0 & & \\
\hline
\end{tabular}

*: univariate analysis was performed; INH: isoniazid; RIF: rifampicin; NC: not calculated because of low number of patients; OR: odds ratio; 95\% CI: 95\% confidence interval. **: including patients with no statement about prior therapy in their medical records. For countries included in Group II see table 3.

in extrapulmonary tuberculosis was caused by a high rate of extrapulmonary tuberculosis in patients from South America, Africa, or Asia (17\%). Table 5 summarizes relevant associations of demographic and clinical data with resistance to antituberculosis drugs, in particular isoniazid and rifampicin.

Prior therapy. A history of antituberculosis drug treatment was the strongest predictor of drug resistance. However, within the group of foreign-born patients, prior therapy was not significantly associated with drug resistance. This indicated limited reliability of information about previous treatment in foreign-born patients; therefore, they were excluded from further analysis of initial and acquired resistance. Among patients born in Germany with a history of previous treatment, drug resistance was more frequent in patients who had last been treated within the preceding $5 \mathrm{yrs}$, than in those who had been treated more than 5 yrs ago (table 5). This effect remained statistically significant when multiple prior therapy was introduced into the analysis as an additional factor, leading to an adjusted odds ratio of 5.7 (95\% CI, 2.2-14.7); simultaneously, a history of multiple therapy courses was no longer significantly associated with drug resistance. In the subgroup of patients having been treated within the last 5 yrs, drug resistance was significantly more frequent in patients with multiple prior therapies than in those with single therapy. Within the subgroup of patients with previous treatment more than 5 yrs ago, multiple therapy was not a significant risk factor. Organisms resistant to isoniazid or rifampicin were isolated from 10 of 698 patients who were born in Germany and had no history of prior therapy. Two of these patients had organisms resistant against rifampicin only, with a history of tuberculosis in several family members in one case. One of the 10 patients, an 18 year old woman, had an isolate resistant against isoniazid and rifampicin.
Country of birth. The association of drug resistance with country of birth is demonstrated in tables 1-5. Patients from South America, Africa, or Asia were more likely to have resistant organisms than patients from other countries. Of seven patients from Peru, five had isolates resistant to isoniazid and three had isolates resistant to isoniazid and rifampicin. The frequency of drug-resistant tuberculosis did not differ significantly between patients from foreign European countries, including the former Soviet Union and Turkey, and patients born in Germany. Three of seven patients from Romania had resistant isolates, one showing resistance against isoniazid and none showing resistance against rifampicin. Considering only resistance to one or more drugs, patients from Turkey did not carry a significantly increased risk of resistance. However, seven patients from Turkey had organisms resistant to isoniazid, with two being also resistant to rifampicin. Hence, $11 \%$ of 61 patients from Turkey had isolates resistant to isoniazid or rifampicin versus $4.5 \%$ of 799 patients born in Germany (OR 2.7; 95\% CI 1.2-6.5).

Age. Patients up to $30 \mathrm{yrs}$ of age were less likely to have been treated previously $(\mathrm{p}=0.0001)$ and more likely to come from South America, Africa or Asia $(\mathrm{p}<0.0001)$. The age distribution within the groups at risk for drug resistance is shown in table 6. Among patients born in Germany without a history of antituberculosis drug treatment, resistance to one or more drugs was significantly more frequent in patients up to $30 \mathrm{yrs}$ of age than in older patients (table 5). However, only 2 of 10 young patients with resistant organisms had isolates resistant to isoniazid or rifampicin, whereas seven had organisms resistant to streptomycin only.

\section{Discussion}

Our study shows no change in the proportion of drugresistant tuberculosis within an in-patient population in 
Table 6. - Age distribution of patients with a history of antituberculosis drug therapy and patients from Group II countries

\begin{tabular}{|c|c|c|c|c|c|c|}
\hline \multirow{3}{*}{$\begin{array}{l}\text { Age } \\
\text { yrs }\end{array}$} & \multicolumn{3}{|c|}{ Prior therapy } & \multicolumn{3}{|c|}{ Group II } \\
\hline & \multirow{2}{*}{$\begin{array}{l}\text { Pts } \\
n\end{array}$} & \multicolumn{2}{|c|}{$\begin{array}{c}\text { Resistant to } \\
\geq 1 \text { drugs } \\
\end{array}$} & \multirow{2}{*}{$\begin{array}{l}\text { Pts } \\
n\end{array}$} & \multicolumn{2}{|c|}{$\begin{array}{l}\text { Resistant to } \\
\geq 1 \text { drugs }\end{array}$} \\
\hline & & $\mathrm{n}$ & $\%$ & & $\mathrm{n}$ & $\%$ \\
\hline$\leq 30$ & 13 & 5 & 38 & 47 & 14 & 30 \\
\hline $31-45$ & 35 & 9 & 26 & 30 & 6 & 20 \\
\hline $46-60$ & 43 & 17 & 40 & 6 & 2 & 33 \\
\hline$>60$ & 41 & 9 & 22 & 6 & 1 & 17 \\
\hline
\end{tabular}

Pts: patients. For countries included in Group II see table 3.

Germany during the last decade. Prior antituberculosis drug therapy and origin from South America, Africa or Asia were strongly associated with drug resistance. Patients who received antituberculosis drugs in recent years were more likely to harbour resistant organisms than patients with a more remote history of drug treatment. There was also an association of drug resistance with age.

The resistance rates observed in our study have to be compared with those of a study covering the period 1976-1982 in another hospital in former West Germany [14]. This author found a resistance rate of $0.8 \%$ for rifampicin, compared to $2.4 \%$ in our patients. The proportion of previously treated patients was not mentioned, and the only information as to foreign-born patients was a proportion of $8.1 \%$ foreigners in 1982 . Another study evaluating only initial antituberculosis drug resistance among patients from several institutions in former West Germany from 1972 until 1975 allows a more detailed comparison [17]. In this study, 5.5 and $2.8 \%$ of German patients had isolates resistant to one or more drugs and to isoniazid, respectively, and $0.1 \%$ of all patients had isolates resistant to rifampicin. In our population, 4.2 and $1.1 \%$ of patients born in Germany had organisms showing initial resistance to one or more drugs and to isoniazid, respectively, and $0.9 \%$ of all patients $(0.4 \%$ of patients born in Germany, $2.3 \%$ of foreign-born patients) had organisms showing initial resistance to rifampicin. In conclusion, there appears to be an increase of resistance against rifampicin from the seventies to the eighties, presumably reflecting the more widespread use of this drug. For the years 1991 and 1992, an evaluation of questonnaires sent to laboratories throughout Germany yielded overall resistance rates of $5.4 \%$ for isoniazid and $1.4 \%$ for rifampicin [13]. The higher rate of rifampicin resistance in our study may result from regional differences and a bias attributable to the restriction to an in-patient population.

Mycobacterium tuberculosis is not able to transfer the genetic information for drug resistance within the bacterial population. All resistance occurring at a higher rate than mutational resistance $\left(10^{-6}\right.$ per cell division for isoniazid, ethambutol or streptomycin, $10^{-8}$ for rifampicin) results from selection by failed drug treatment [18]. For surveillance purposes, initial resistance indicates treatment failures in the past, whereas acquired resistance indicates treatment failures at the present time. Naturally, retrospective surveys tend to underestimate the presence of study factors like prior therapy, and some cases of acquired resistance may be misclassified as initial resistance. Among patients born in Germany, we observed initial and acquired resistance in 4.2 and 32\%, respectively. Taking two extremes for comparison, the corresponding numbers are 23 and $44 \%$ for New York City [3], and 1.4 and $15 \%$ for former East Germany [15]. Thus, resistance rates may not have increased in our population, but possibly they are not as low as feasible.

To our knowledge, this study is the first to show recent therapy as an additional risk factor in previously treated patients, having considered multiple prior therapy courses as a confounding factor. Two hypotheses could explain this phenomenon: firstly, the quality of tuberculosis therapy could have deteriorated enforcing the development of resistant mycobacteria. Unfortunately, the medical records did not contain sufficient data to allow an evaluation of factors which contribute to the quality of therapy, such as number of drugs, dosage, and treatment duration. Secondly, the association could be the result of a selection process: relapses after adequate therapy are usually caused by sensitive organisms [19], and drug-sensitive mycobacteria are thought to survive adequate therapy as long as they are dormant [20]. Sensitive bacteria could, therefore, take longer to cause a relapse than resistant bacteria. However, at present there are no data available to substantiate this speculation.

The inverse correlation between initial antituberculosis drug resistance and age is in accordance with the findings reported by other authors [21]. This relationship might be explained by the fact that young patients inevitably contracted their infections at a time when there were already infectious sources with acquired resistance. In our population, the association of drug resistance with age was due to an increased rate of streptomycin resistance in patients up to $30 \mathrm{yrs}$ of age, which supports the aforementioned explanation.

Our results suggest that a history of antituberculosis drug therapy is of little value for the prediction of drug resistance in foreign-born patients. To some extent, this may be due to the more frequent transmission of resistant bacteria in areas with a high prevalence of tuberculosis. On the other hand, language barriers, uncontrolled availability of antituberculosis drugs, and reluctance to reveal prior disease may effect a loss of information.

Foreign-born patients as a whole carried a higher risk of harbouring drug-resistant organisms. However, the present study illustrates that the distinction between foreign-born patients and patients born in Germany is too crude to guide treatment decisions. For statistical purposes, we defined two groups of countries of origin. Patients from South America, Africa, or Asia were at risk for drug resistance, whereas patients from Europe including the former Soviet Union and Turkey were not. But within these groups, there again appeared to be differences, as the high rate of antituberculosis drug resistance in patients from Peru suggests. There are other observations indicating areas with a high rate of drug-resistant tuberculosis in Eastern Europe [22]. It is obvious that our study, at best, can reflect the situation in 
the patients' countries of origin with a time lag. In some countries, resistance rates have changed remarkably within one decade. For example, in Korea, the resistance rate decreased from $48 \%$ in 1980 to $25 \%$ in 1990 after reorganization of the tuberculosis control programme [23]. For countries with a large number of foreign-born tuberculosis patients, information about the distribution of antituberculosis drug resistance in the world is of great importance. The World Health Organization (WHO) and the International Union Against Tuberculosis and Lung Disease (IUATLD) are establishing a surveillance system for drug-resistant tuberculosis, trying to overcome the methodological limitations of previous studies [24].

HIV infection has been reported to be associated [3], and not to be associated [25], with drug-resistant tuberculosis. As far as HIV infection is associated with risk factors for treatment failure, such as intravenous drug use and homelessness, its association with antituberculosis drug resistance is understandable [26]. Since tuberculosis progresses more rapidly to active disease in HIV-infected patients [27], the pattern of resistance in these patients may also herald the future pattern in the general population. The HIV serostatus was documented in $11.4 \%$ of our patients, and only four patients were seropositive. This may, in part, be due to the absence of special facilities for the treatment of patients with AIDS at our hospital. Since tuberculosis is an AIDS-defining illness and tends to occur early in the course of AIDS [28], it might be reasonable to determine the HIV status in tuberculosis patients regularly. Representative data about the rate of HIV infection in tuberculosis patients in Germany are lacking. In Frankfurt, $4.0 \%$ of tuberculosis patients in 1989 were HIV-seropositive [29]. The incidence of AIDS in Frankfurt is twice as high as in Hamburg and 13 times as high as in Schleswig-Holstein [30]. The impact of HIV infection on the incidence of tuberculosis is expected to be small in areas, where HIV infection is largely confined to risk groups, and where the prevalence of tuberculosis infection in the population aged 15-50 yrs is low [31]. In Germany, the former is true [30] and the latter is assumed, but there are no age-specific data as to the prevalence of tuberculosis infection.

Naturally, a hospital-based study can only provide limited information about the prevalence of drug-resistant tuberculosis in the community. In-patients tend to have more serious disease, and a selection bias favouring patients with a history of treatment failure and, therefore, at risk for drug-resistant tuberculosis is likely. However, in the absence of community-based data from the past, information from the hospital is the only information available on the time course of drug-resistant tuberculosis.

Very recently, two other studies on drug-resistant tuberculosis in Germany have been published. A study performed in Berlin [32] reported a constant rate of resistance to one or more drugs from 1987 to 1993 and an increase of resistance to two or more drugs, the latter being defined as multidrug resistance. In the present study, we followed the common definition as resistance to both isoniazid and rifampicin, which appears to reflect clinical experience more closely [8]. This difference in definition severely hampers the comparison of the data. For example, it can be inferred that less than one third of the isolates classified as multidrug-resistant in the study from Berlin would have satisfied our definition of multidrug resistance. Nevertheless, the results of both studies appear to be compatible if the variability of prevalence estimates is taken into account. This conclusion is supported by an analysis of a large set of laboratory data from Frankfurt [33], which also demonstrated no increase of single drug or multidrug resistance over the period 1980-1993.

Our data do not support the hypothesis that there is an increase of drug-resistant tuberculosis in Germany. However, further surveillance is indicated, particularly in areas with a large burden of HIV infection, homelessness, and other features of disadvantaged living conditions. Furthermore, our findings suggest that for the majority of not previously treated patients, standard antituberculosis treatment with three drugs (isoniazid, rifampicin, pyrazinamide) for 2-3 months and two drugs (isoniazid, rifampicin) for additional $4-6$ months is sufficient. They also indicate that patients with a history of antituberculosis drug therapy, in particular if they were treated within recent years, and patients from South America, Africa or Asia should be considered having drug-resistant tuberculosis until proven otherwise. Consequently, the initial treatment of these patients should consist of four drugs (isoniazid, rifampicin, pyrazinamide, ethambutol). A modified approach may be justified in some previously treated patients after thorough questioning about prior medication and compliance.

At least as important as to choose the right regimen is to assure adherence. An approach based on public health nurses has led to a decline of both tuberculosis and antituberculosis drug resistance, without imposing directly observed therapy on all patients [34]. Since physicians are not able to predict adherence [35], the need for directly observed therapy is difficult to assess. Drug-resistant tubercle bacilli are as infectious as sensitive ones [36], and patients with drug-resistant tuberculosis may spread their bacilli for longer periods of time. Almost two thirds of cases of drug-resistant tuberculosis in New York City seem to result from recent transmission [37]. Case recognition and the application of established measures to prevent transmission [38] are essential for the containment of drug-resistant tuberculosis. With regard to developing countries and disadvantaged groups in industrialized countries, it may be helpful to recognize that most of the decline of tuberculosis since the eighteenth century in parts of the world was not due to medical intervention, but to improved nutrition, lessened environmental hazards, and decreased human reproduction [39].

Acknowledgement: The authors wish to thank R. Urbanczik for his critical comments on the manuscript. 


\section{References}

1. Bloch AB, Cauthen GM, Onorato IM, et al. Nationwide survey of drug-resistant tuberculosis in the United States. J Am Med Assoc 1994; 271: 665-671.

2. Kleeberg HH, Olivier MS. A world atlas of initial drug resistance. Pretoria, Medical Research Council, 1984.

3. Frieden TR, Sterling T, Pablos-Mendez A, Kilburn JO, Cauthen GM, Dooley SW. The emergence of drugresistant tuberculosis in New York City. $N$ Engl J Med 1993; 328: 521-526.

4. Centers for Disease Control. Nosocomial transmission of multidrug-resistant tuberculosis among HIV-infected persons: Florida and New York, 1988-1991. Morb Mort Weekly Rep 1991; 40: 585-591.

5. Centers for Disease Control. Outbreak of multidrug resistant tuberculosis: Texas, California and Pennsylvania. Morb Mort Weekly Rep 1990; 39: 369-372.

6. Bloom BR, Murray CJL. Tuberculosis: commentary on a re-emergent killer. Science 1992; 257: 1055-1064.

7. Mitchison DA, Nunn AJ. Influence of initial drug resistance on the response to short-course chemotherapy of pulmonary tuberculosis. Am Rev Respir Dis 1986; 133: 423-430.

8. Goble M, Iseman MD, Madsen LA, Waite D, Ackerson L, Horsburgh CR. Treatment of 171 patients with pulmonary tuberculosis resistant to isoniazid and rifampin. N Engl J Med 1993; 328: 527-532.

9. Iseman MD. Treatment of multidrug-resistant tuberculosis. N Engl J Med 1993; 329: 784-791.

10. Etemadi A, Farid R, Stanford JL. Immunotherapy for drug-resistant tuberculosis. Lancet 1992; 340: 1360 1361.

11. Raviglione MC, Sudre P, Rieder HL, Spinaci S, Kochi A. Secular trends of tuberculosis in Western Europe. Bull WHO 1993; 71: 297-306.

12. Deutsches Zentralkomitee zur Bekämpfung der Tuberkulose. 20. Informationsbericht. Mainz, 1994.

13. Arbeitskreis Mykobakterien. Erhebungen zur Resistenzlage der Tuberkulosebakterien in Deutschland für das Jahr 1991 und 1992. Pneumologie 1994; 48: 28-29.

14. Petersen KF. Empfindlichkeitsprüfungen von Tuberkulosebakterien: Eine Verlaufsbeobachtung. Prax Klin Pneumol 1983; 37: 385-389.

15. Kalich R. Resistenzhäufigkeit von M. tuberculosis bei stationär behandelten Patienten in Ostdeutschland. Pneumologie 1991; 45: 725-728.

16. Canetti G, Fox W, Khomenko A, et al. Advances in techniques of testing mycobacterial drug sensitivity, and the use of sensitivity tests in tuberculosis control programmes. Bull WHO 1969; 41: 21-43.

17. Matthiessen W, Kind A, Göbel D. Epidemiologie der Primärresistenz von Tuberkulosebakterien in der Bundesrepublik Deutschland einschließlich Berlin (West) im Beobachtungszeitraum 1972 bis 1975. Prax Pneumol 1977; 31: 890-899.

18. Vareldzis BP, Grosset J, de Kantor I, et al. Drugresistant tuberculosis: laboratory issues. Tuberc Lung Dis 1994; 75: 1-7.

19. Snider DE, Long MW, Cross FS, Farer LS. Six months isoniazid-rifampin therapy for pulmonary tuberculosis. Am Rev Respir Dis 1984; 129: 573-579.

20. Mitchison DA. The action of antituberculosis drugs in short-course chemotherapy. Tubercle 1985; 66: 219225.
21. Centers for Disease Control. Primary resistance to antituberculosis drugs - United States. Morb Mort Weekly Rep 1983; 32: 521-523.

22. Burns DN, Gellert GA, Crone RK. Tuberculosis in Eastern Europe and the former Soviet Union: how concerned should we be? Lancet 1994; 343: 1445-1446.

23. Kim SJ, Hong YP. Drug resistance of Mycobacterium tuberculosis in Korea. Tuberc Lung Dis 1992; 73: 219-224.

24. Nunn P, Felten M. Surveillance of resistance to antituberculosis drugs in developing countries. Tuberc Lung Dis 1994; 75: 163-167.

25. Githui W, Nunn P, Juma E, et al. Cohort study of HIV-positive and HIV-negative tuberculosis, Nairobi, Kenya: comparison of bacteriological results. Tuberc Lung Dis 1992; 73: 203-209.

26. Neville K, Bromberg A, Bromberg R, Bonk S, Hanna BA, Rom WN. The third epidemic-multidrug-resistant tuberculosis. Chest 1994; 105: 45-48.

27. Daley CL, Small PM, Schecter GF, et al. An outbreak of tuberculosis with accelerated progression among persons infected with the human immunodeficiency virus: an analysis using restriction-fragment-length polymorphisms. N Engl J Med 1992; 326: 231-235.

28. Pitchenik AE, Burr J, Suarez M, Fertel D, Gonzalez G, Moas C. Human T-cell lymphotropic virus-III (HTLVIII) seropositivity and related disease among 71 consecutive patients in whom tuberculosis was diagnosed: a prospective study. Am Rev Respir Dis 1987; 135: 875-879.

29. Forßbohm M, Schempp R, Valentijn A. HIV-Infektion bei Tuberkulosepatienten in Frankfurt/Main 1982-1989. Atemw Lungenkrkh 1991; 17: 31-38.

30. AIDS-Zentrum im Bundesgesundheitsamt. AIDS/HIV 1993: Bericht zur epidemiologischen Situation in der Bundesrepublik Deutschland zum 31.12.1993. Berlin, 1994.

31. Styblo K. The impact of HIV-infection on the global epidemiology of tuberculosis. Bull Int Union Tuberc Lung Dis 1991; 66: 27-32.

32. Schaberg T, Gloger G, Reichert B, Mauch H, Lode H. Drug-resistant pulmonary tuberculosis in Berlin, Germany, 1987-1993. Eur Respir J 1995; 2: 278-284.

33. Schneider C, Lasch C, Brade V. Haben Inzidenz und Resistenz der Tuberkulose zugenommen? Pneumologie 1994; 48: 803-808.

34. Nardell EA. Beyond four drugs: public health policy and the treatment of the individual patient with tuberculosis. Am Rev Respir Dis 1993; 148: 2-5.

35. Mushlin AI, Appel FA. Diagnosing potential noncompliance: physicians' ability in a behavioural dimension of medical care. Arch Intern Med 1977; 137: 318-321.

36. Snider DE, Kelly GD, Cauthen GM, Thompson NJ, Kilburn JO. Infection and disease among contacts of tuberculosis cases with drug-resistant and drug-susceptible bacilli. Am Rev Respir Dis 1985; 132: 125-132.

37. Alland D, Kalkut GE, Moss AR, et al. Transmission of tuberculosis in New York City: an analysis by DNA fingerprinting and conventional epidemiological methods. N Engl J Med 1994; 330: 1710-1716.

38. Centers for Disease Control. Guidelines for preventing the transmission of tuberculosis in health-care settings, with special focus on HIV-related issues. Morb Mort Weekly Rep 1990; 39: 1-29.

39. McKeown T. The Role of Medicine: Dream, Mirage or Nemesis? Oxford, Basil Blackwell, 1979; pp. 92-96. 